\title{
Anos 60/70 \\ do sonho revolucionário ao amargo retorno
}

\author{
LUCI GATI PIETROCOLLA
}

RESUMO: O objetivo deste artigo é mostrar que a imagem de herói revolucionário, construída nos anos 60/70 na luta contra a ditadura no Brasil, tornou-se, para as pessoas que participaram dessa luta, a referência pessoal mais importante. Esta questão foi analisada a partir do retorno do exílio e do não-retorno, ou seja, daqueles que permaneceram no país de acolhimento até os dias de hoje.

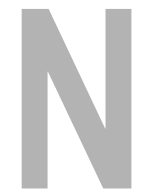

o momento presente, quando representantes da chamada "geração 68 " chegam ao poder e se distribuem pelos diferentes partidos políticos, desde os setores mais radicais de esquerda aos mais conservadores, o compromisso e o ideal revolucionários que, nos anos 60/70, os reunia numa "comunidade de destino", aparecem estilhaçados, às vezes irreconhecíveis. Parece que se perderam no tempo as motivações que, no passado, os levaram a abraçar a causa.

Se ontem uma disposição revolucionária colocou muitos jovens na vanguarda dos movimentos pela transformação social, justificando o exílio, a clandestinidade e as prisões, hoje, outro contexto histórico - marcado pela fragmentação e pela dificuldade global de se construir um projeto voltado para a humanização do homem - provoca a emergência de novas situações e compromissos. Como se pensar, neste novo contexto, a identidade revolucionária?

Parto do princípio que, para muitos, o sonho ainda não acabou. A identidade revolucionária persiste, se reatualiza, se transfigura. Nas brechas do sistema político brasileiro, quase monolítico, uma oposição fundada na identidade revolucionária dos anos 60 e 70 encontra suporte para a ação política.
UNITERIMOS: herói revolucionário, identidade, exílio, clandestinidade, retorno.

Professora do Departamento de Serviço Social da UNESP. Franca 
Os mesmos ideais que sustearam a luta no passado se reatualizam e orientam a ação política no presente. Dos mais altos postos no legislativo e executivo até comissões, núcleos e organizações de movimentos comprometidos com os direitos humanos e com o avanço da democracia, os ex-revolucionários vão se pronunciando. Militando nos moldes de 68 reatualizados ou não, vão preenchendo os possíveis espaços políticos e participando de diferentes movimentos sociais.

Procuro, neste artigo, apontar os ajustes na identidade revolucionária no período pós-Anistia. Assim, o significado do retorno é analisado através de duas situações registradas pela pesquisa empírica: a) exilados que voltaram com a lei da Anistia; b) os que partiram para o exílio, lá permanecendo até os dias de hoje.

Retornar é realizar a viagem de volta para uma casa cuja porta está aberta. De par com o medo e a esperança, prevalecendo esta sobre aquele, o retorno diz respeito a um tempo e um espaço de ausência. Re-estabelecer, reconhecer, re-tomar, re-tornar... significam a virtual possibilidade de viver uma experiência amorosa já conhecida. Neste sentido, o momento do retorno vem carregado de um conteúdo emocional intenso, porque passado, presente e futuro misturam-se na construção quase obstinada de uma vida presente-futura. Ele estabece um limite no tempo e no espaço à experiência do viver entre parênteses, construída como resistência, bem como legitima o caráter de transitoriedade desta experiência:

"Para Ulysses, Ítaca é o centro do mundo, seu eixo arquimediano, o ponto fixo. Porém, o repatriado não encontra em sua pátria aquilo que procurava, não reconhece seu 'lugar natural'. Quando volta, ele mesmo está mudado e Ítaca não permanecerá tampouco a mesma. A terra natal transforma-se em terra estranha, por uma dialética sutil do espaço e do tempo: Ulysses reencontrará, pois, sua Ítaca lá mesmo onde a havia deixado; mas o Ulysses de outrora, aquele que deixou sua ilha, ele não encontrará mais. Ulysses é agora outro Ulysses que reencontra outra Penélope. E Ítaca é também uma outra ilha, no mesmo lugar, mas não na mesma data. A viagem no espaço é uma viagem no tempo, e o ponto de chegada, o ponto fixo ansiado não existe, deixando-nos à deriva. $O$ deslocamento no espaço produz a ilusão da mudança, mas é no tempo que tudo muda" (Matos, 1988, p. 154-155).

${ }^{1}$ No sentido utilizado por Ecléa Bosi (1987). 
GATI PIETROCOLLA, Luci. Anos 60/70: do sonho revolucionário ao amargo retorno. Tempo Social; Rev. Sociol. USP, S. Paulo, 8(2): 119-145, outubro de 1996.

das situações estudadas ter seu próprio tempo, ritmo, ciclo e movimento, é no tempo, enquanto representação social, que as mudanças são registradas e, desse modo, apreendidas nas falas dos personagens. As rememorações do passado no presente o confirmam. As mudanças pelas quais passaram os indivíduos nas diferentes situações têm um significado particular mas o registro delas se realiza num tempo que é comum a todos. Se o medo e a esperança regeram o viver entre parênteses ${ }^{2}$, a experiência do retorno é igualmente regida por estes mesmos sentimentos matizados, contudo, pela nostalgia.

$\mathrm{O}$ interessante da pesquisa empírica foi a revelação de que a identidade revolucionária passou por transformações, mas é ela que no presente ainda assegura a construção da imagem que o indivíduo tem de si mesmo. No Brasil ou no país que ofereceu asilo político, no caso a França, as imagens e representações compreendidas nas falas dos entrevistados mostraram que nem o tempo conseguiu erodir esta imagem matizada e reatualizada, mas nunca perdida. A imagem do herói revolucionário é no presente a marca do passado que funda ainda nos dias de hoje a imagem que o indivíduo tem de si.

As duas situações foram tratadas de modo desigual. O retorno do exílio mereceu maior espaço de escrita por se tratar de uma situação paradigmática. Uma vez que as mudanças foram mostradas ao longo de um tempo, optou-se por tratar a outra situações de modo sumário, evitando repetições.

\section{O retorno do exílio}

\section{"[...] ele viveu doze anos com a mala em cima da cama esperando para voltar!" (frase da companheira de um ex-exilado em Paris).}

Ao retornar ao país de origem o revolucionário se depara com uma terra estranha. O Brasil dos anos 80 não era mais o dos anos 60 . O tempo erodiu e transformou sonhos e realidades. Retornar é dispor-se a novos enfrentamentos.

Ulysses retorna como um novo homem numa Ítaca que não é a mesma, "está no mesmo lugar mas não na mesma data. [...] Ulysses se torna melancólico porque o objeto renunciado continua a ser desejado. Nas análises freudianas, essa impossibilidade de abandonar o objeto amadoé a fonte natural da tristeza. Freud, porém, distingue a tristeza da melancolia: 'A tristeza', escreve Freud, 'é geralmente a reação à perda de um ser amado ou de uma abstração equivalente: a pátria, a liberdade e o ideal [...] O exame da realidade mostrou que o objeto amado já não existe e exige que a libido abandone todas as relações com o mesmo [...]'. A melancolia também constitui, continua Matos, uma "reação à perda de um objeto amado [...] mas não conseguimos distinguir claramente o que o sujeito perdeu e devemos admitir que a ele é impossível concebê-lo claramente. O melancólico causa uma impressão enigmática porque não se pode descobrir o que é que o absorve tão intensamente" (Matos, 1988,
${ }^{2}$ Esta categoria foi criada para dar conta de três situações paradigmáticas - a clandestinidade, o exílio e as prisões nomeadas da experiência dos perseguidos políticos pela ditadura militar nos anos 60/70 (cf. Gati Pietrocola, 1995). 
p. 149-150). Por ocorrerem no tempo que tem o componente da abstração, as mudanças são mais sentidas do que palpáveis e, neste sentido, "Ítaca está no mesmo lugar mas não na mesma data”. É necessário o re-conhecimento das mudanças ocorridas no tempo que extrapola o social e se fixa no particular, representado pela imagem que o indivíduo tem de si. O viver entre parênteses favorece o afloramento de modo mais intenso da imagem que o revolucionário tem de si. A transformação dessa imagem ao longo dos anos independe do espaço físico que ele vive - Brasil ou exterior -, ela dá concretude à noção de tempo. A incorporação da noção e utilização do tempo no país de acolhida demanda um lento aprendizado porque o indivíduo passa a ter um duplo sistema de referências: o do seu país de origem e o do país que lhe ofereceu acolhimento.

Tomando a referência do tempo nas sociedades primitivas e nas industrializadas, Vasquez (1982c) chama a atenção para as particularidades da noção e da utilização do tempo nestas últimas formações sociais. Nelas, o tempo do trabalho é marcado pelo relógio. A abordagem que faz tem como propósito chamar a atenção para o fato de que a vida social e, mais precisamente, as atividades cotidianas produzem os tempos sociais e lhe dão características específicas. Marcado pelo relógio, o tempo linear dá uma especificidade ao tempo nas sociedades industrializadas. Incrustado na cultura, o significado do tempo não aflora na consciência dos indivíduos, a não ser em momentos particulares.

A partir do exposto, observou-se que o tempo no viver entre parênteses não é regido pela linearidade do tempo do relógio no sentido apontado, mas por um tempo marcado pela transitoriedade. Assim, não é o sentido do tempo que se busca conhecer mas o sentido de um tempo peculiar, o do viver entre parênteses rememorado no presente à luz da experiência. Num tempo particular (como o do viver entre parênteses) fica mais transparente o significado do tempo como categoria social construída num cotidiano específico, cuja característica é a transitoriedade.

Ciro, que junto com Elisa e Matheus viveu no exílio durante mais de dez anos, relata as mudanças:

"Quando retornei, eu estava compenetrado que não era a mesma coisa... Eu tinha muito empenho em recuperar o tempo perdido... Eu perdi, vamos dizer, não perdi... mas do ponto de vista profissional eu fiquei doze anos fora do Brasil, fora da minha profissão... Eu era muito competitivo na minha época, eu fiquei fora da competição. Queria voltar, queria recuperar o tempo perdido, queria provar que eu, que eu continuava válido, capaz... Aí aconteceram várias coisas... ninguém me ofereceu nenhuma oportunidade de trabalho, apesar de eu ter ótima reputação profissional; mas ninguém se lembrou... eu dei várias chances... perguntei a várias pessoas... 
eu não ia responder anúncios nem me oferecer diretamente mas procurei meus amigos e ninguém me ofereceu nenhuma chance. Eu pensei... boméque eles têm medo... porque ainda não era o Brasil que é hoje... Havia a Anistia, mas pessoa não fiava... então, ninguém, nenhuma Alcântara Machado vai se dar ao luxo de ter uma pessoa que possa desgostar a Volkswagen... E por outro lado, eu tinha muita insegurança... Será que eu sou mesmo capaz?... Será que eu quero reassumir tudo isso?... Será que eu já não sou outra pessoa... tô querendo ser mas não sou mais? Assim como eu vi muita mudança em São Paulo, mudança física... eu podia também estar completamente mudado... Então, por isso, eu conservei um pique na Espanha... eu me separei de Elisa e vim com uma namorada espanhola... Vivi uns tempos com ela aqui... mas [...] desfiz a casa e voltei pra Espanha em 86... Quando cheguei lá vi... me dei conta que lá não era o meu lugar... vivia permanentemente de mau humor... Aí me deu estalo... Eu disse, agora acabou o meu exílio... seis anos depois! Aí eu voltei com ânsia mesmo de me integrar. Ah! quando eu voltei... não fui trabalhar na minha profissão... fui trabalhar numa coisa que não tinha nada a ver comigo... Você vem à procura de algo que já não existe... querendo colocar nesse lugar que já não existe uma pessoa que também já não é a mesma... também mudou... Mudou tudo... as pessoas, os amigos... Você congela na memória aquela imagem... de repente você vê uma nova imagem... de uma pessoa envelhecida... A superposição é muito difícil e nela você vê o espelho de você mesmo...

A reintegração é talvez mais complicada que o exílio, porque no exílio é tudo novidade, expectativa diante do desconhecido... [...] a gente achava muito engraçado este negócio de terrorista... nós éramos guerrilheiros... Tinha toda uma aura de romantismo na figura do guerrilheiro... e quando a gente passava nos aeroportos... A gente tinha uma Carteira de Residente Estrangeiro dada pela ONU aos refugiados políticos... a gente ficava duas horas no aeroporto, nos faziam mil perguntas... Também, viajando assim com documentos tão precários!! Mas não era uma coisa que pesasse pra gente... porque tinha uma aura 
em torno da gente... No exílio você se sente herói, porque você participou de alguma ação excepcional... não é a toa que você é procurado pela polícia... E quando você retorna este herói não existe... Eu fazia exercícios pra cair na realidade... Então eu ganho minha vida fazendo coisas absolutamente desinteressantes "3.

Na impossibilidade de manter e garantir a identidade colocada num "rosto profissional", a exigência da preservação da imagem de si implica o retorno para "recuperar o tempo perdido". Mais do que isto, Ciro afirma: "para provar que eu continuava válido, capaz...". O viver entre parênteses, retirando o sujeito do meio, corta as suas ligações com o mundo do trabalho e dos afetos originais. Outras experiências vão se colocando. No caso do exílio, houve a possibilidade de construir uma nova identidade reconhecida socialmente: a de exilado político. O mesmo não ocorreu para os que permaneceram no Brasil em clandestinidade, estigmatizados como terroristas. Segundo Vasquez e Apfelbaum (1983), situações de mudanças bruscas ou mesmo etapas marcantes da vida, que não são necessariamente aquelas de desenraizamento geográfico, favorecem a desestruturação ou a reestruturação da identidade. No caso dos exilados, após um período de rupturas bruscas e dilaceramento foi ocorrendo lentamente a reestruturação do eu e a reconstrução da identidade. Às perdas e violências sofridas, novas conquistas foram se instalando. Novos amores foram surgindo. Filhos foram nascendo, outras experiências políticas, profissionais e sociais foram requerendo a integridade e uma nova postura diante da vida. Outros desafios, assim, foram surgindo e demandando revisão ideológica, de princípios e de comportamento.

No Brasil, o estatuto político de revolucionário era reconhecido até mesmo pela ditadura. A perseguição, conduzindo-os ao viver entre parênteses e à desestruturação decorrente das mudanças, provocou, ao longo dos anos, questionamentos em relação à própria imagem, favorecendo, em muitos casos, o reforço do estatuto de revolucionário. Para os exilados, esse processo era reforçado pelos comitês de auxílio a refugiados políticos que ajudavam a integração desses grupos no país de acolhimento. "Nós éramos guerrilheiros... tinha toda uma aura de romantismo na figura do guerrilheiro... [...] no exílio você se sente herói porque você participou de alguma ação excepcional...". Para muitos, a participação da comunidade de exilados no processo político de denúncia da ditadura militar nas suas mais variadas formas contribuía de um modo mais visível e seguro para a reconstrução da identidade.

Estudando a questão da identidade de exilados políticos da América do Sul, Vasquez e Apfelbaum (1983) afirmam: "O estatuto do exílio favorece um reagrupamento que obscurece as diferenças e as contradições e exalta, ao contrário, a participação comum nas lutas de seu país e no projeto

3 Depoimentos colhidos pela autora. compartilhado de restauração da democracia. A qualidade de exilado é uma garantia de pertencer a um grupo de modo que, por uns tempos, é possível 
GATI PIETROCOLLA, Luci. Anos 60/70: do sonho revolucionário ao amargo retorno. Tempo Social; Rev. Sociol. USP, S. Paulo, 8(2): 119-145, outubro de 1996.

escapar do processo que faz 'invisível' aquele que é acolhido no seio da nova sociedade. Isto não impede, entretanto, que ocorra, em alguns exílios, problemas de identidade relativamente graves; mas eles diminuem bastante, neste período inicial de exílio, o traumatismo e os processos de dor consecutivos do desenraizamento e das perdas afetivas decorrentes dos golpes de Estado" (Vasquez e Apfelbaum, 1983, p. 80). Ou seja, uma história e expectativas comuns são compartilhadas e discutidas no exílio, fortalecendo o processo de reconstrução de identidade pessoal e do grupo social.

Há que se considerar também que o exilado está sujeito "à novidade e expectativa diante do desconhecido". Esta situação projeta uma certa esperança diante do novo e uma alegria pelo fato de haver conseguido se salvar. No retorno, os mesmos sentimentos alimentam o desejo de integrar-se rapidamente no país já conhecido. Mas este país mudou, não é mais o mesmo: "você vem à procura do que já não existe... querendo colocar nesse lugar que já não existe uma pessoa que já não é a mesma... também mudou... mudou tudo... as pessoas, os amigos... Você congela na memória aquela imagem... de repente você vê uma nova imagem... de uma pessoa envelhecida... A superposição é muito difícil e nela você vê o espelho de você mesmo...". As perdas são reais, mas por se concretizarem no tempo que tem como componente a abstração, realizam-se na nostalgia. A viagem é dentro de si e não há lugar de repouso. A nostalgia é o mal do exílio para cujo remédio só existe o retorno. A consciência, a impossibilidade de regresso e o sentimento nostálgico dão ao exilado um "destino patético", nas palavras de Jankélévitch. Ele vive em dois mundos: um concreto, mediado pelas tarefas prosaicas próprias do cotidiano, construído pela realidade vivenciada por qualquer ser humano; o outro, o da nostalgia pela terra natal distante, longínqua e que se inscreve, subjetivamente, como a eterna presença da ausência. Neste sentido, presença e a ausência são sentimentos multipresentes na consciência nostálgica: estão em todo lugar e em lugar nenhum (cf. Jankélévitch, 1974).

Ao analisar a presença desses dois mundos, Jankélévitch mostra que o espaço nostálgico tem a ver com o espaço concreto que é a cidade natal. Ulysses sentia saudade da mulher amada, da casa, da rua. É um valor que configura esta situação, colocando a cidade natal como algo santo, bento, querido, que evoca encantamento e magia. $\mathrm{O}$ amor, assim, como a nostalgia, fabrica lugares santos: condensa-se no valor em torno da casa onde habita a mulher amada, que se estende à rua onde se encontra essa casa, ao quarteirão onde se encontra essa rua, e depois, por extensão de encantamento, à cidade inteira da qual o quarteirão faz parte. Uma magia ocupa o coração amoroso. Nesse sentido, o autor entende que o destino do exilado é um destino patético. Compara o homem a uma planta que se enfraquece quando é transplantada; só que enquanto a planta desconhece esse processo, o homem destila a própria melancolia. Ele entrevê a causa da tristeza e adivinha-lhe o remédio: neste complexo ambivalente, composto de um mal e de um remédio ele reconhece a nostalgia. Embora acredite que todos os homens, pela própria condição humana, 
4 "A escolha do exílio foi difícil 'porque os exilados estavam tomados por um profundo sentimento de falta e de perda, por uma tristeza pesada semelhantes àquela experimentada por ocasião da morte. Sós, mas também em grupo, deveriam passar pelo que em psicologia se chama trabalho de elaboração da morte. Seria necessário, não somente chorar os seus mortos, mas assumir a falência de seu projeto e aceitar o fato da sua impossibilidade durante um período de tempo cuja duração não se conhecia, de reencontrar o mundo que foram obrigados a deixar. Assim, a dor é ambígua: em meio aos sofrimentos e desesperança, cada exilado já experimentou o fascínio do sonho, da certeza quase sem pudor de estar vivo, de existir. Ele se sente sufocado de ódio, como se tivesse traído seus mortos se permitindo esquecê-los. É têm um espaço nostálgico no coração, conclui que a concretude do exílio ilumina e prioriza este espaço. Para Ulysses, o retorno é o momento especial porque é quando pode aplicar a justiça e a vingança. É a recuperação do seu status anterior e a restauração da ordem anterior. Retomando Matos, a "terra natal transforma-se em terra estranha, por uma dialética sutil do espaço e do tempo, pois o deslocamento no espaço produz a ilusão da mudança, mas é no tempo que tudo muda" (Matos, 1988, p. 154-155). O reencontro consigo mesmo "de uma pessoa envelhecida que fazia exercícios para cair na real" conforme expressão de Ciro, confirma que esta viagem é outra, é mais dentro do que fora de si mesmo.

Vasquez e Araújo (1988), ao estudarem os exilados latinoamericanos na França, definem três etapas como adequadas para se entender a vida no exílio, tendo em vista a sua própria representação. A primeira referese ao momento da partida, marcada pelo trauma da dor e das perdas. Uma rejeição inicial da cultura do país de acolhida somada à necessária submissão cultural é interpretada pelas autoras como o processo de transculturação. Este diz respeito à incorporação da cultura do país que o abriga, considerada a segunda etapa do processo, como também a essência da etapa seguinte, o retorno. Estes sentimentos, somados à interdição do retorno, tornam o exilado político um "sem lugar", mesmo no país que o acolheu. Assim, não existe rigidez na sucessão das etapas que estabelecem diferentes momentos para a construção da nova identidade. Elas constituem tão-somente um recurso metodológico para a apreensão da realidade do exílio. Elementos de uma etapa estão presentes na outra por se tratarem de sentimentos contraditórios presentes na construção da sua nova imagem.

Conforme demonstram Vasquez e Araújo (1988), a interdição do retorno é mitificada. As autoras o apresentam em dois níveis: um aparente, no qual o projeto político implica a vontade e necessidade do retorno; e outro, inconsciente, no qual os mitos refletem desejos profundos: Ulysses, interditado de voltar a Ítaca, transforma-a no nível do inconsciente, no paraíso perdido, objeto de desejo nunca alcançado. Esta idealização, segundo os autores, é alimentada pela nostalgia. O retorno se faz na direção de uma Ítaca mítica onde Ulysses era rei, conhecido, respeitado e amado. Fundados neste elementos, Vasquez e Araújo afirmam que o retorno significa mais o desejo inconsciente de reencontrar o tempo, a juventude, do que desejo de retornar a um determinado lugar marcado pela geografia. Estabelecem a diferença entre o exílio daqueles que permanecem um longo tempo no estrangeiro - situação na qual a idealização é marcada pela nostalgia - e o exílio dos latino-americanos, quando a idealização se manifesta pela revalorização do país e de seus símbolos. Reinterpretando o mito de Ulysses, afirmam que a interdição do retorno para o exilado político aparece como punição em virtude de um erro cometido, o que acarreta um profundo sentimento de culpa. Dentro dessa ótica, este sentimento coloca o exilado como aquele culpado de tudo e por tudo ${ }^{4}$.

A espera da "verdadeira vida", assentada no estado de culpa e de 
GATI PIETROCOLLA, Luci. Anos 60/70: do sonho revolucionário ao amargo retorno. Tempo Social; Rev. Sociol. USP, S. Paulo, 8(2): 119-145, outubro de 1996.

ausência seria redimida pelo retorno, mas a inviabilidade ante a interdição transforma o país num objeto de desejo, o paraíso perdido. Nostalgia e culpa são sentimentos predominantes na vida do exilado político. Os que morreram na luta e os que permaneceram em clandestinidade são os fantasmas que acompanham sua vida. O retorno ao país de origem é o grande sonho que, contraposto à realidade transformada e às dificuldades encontradas, pôde alimentar nostalgias e culpas que não se findam com o ato de retornar. $\mathrm{O}$ caminho das dores é mais longo...

Segundo a lenda grega recontada por Vasquez e Araújo, Ulysses matou os pretendentes de Penélope, foi julgado pelo grande júri de Ítaca e condenado a deixar mais uma vez seu país, banido por dez anos. O triste paradoxo remete à inexorabilidade do destino e sugere a eterna presença de sentimentos que independem do espaço geográfico ou físico porque é ao psíquico que ele se refere. A juventude já não existe e o envelhecimento, um outro tempo, é a dura realidade. Tomemos as palavras de Ciro: "você congela na memória aquela imagem... de repente você vê uma nova imagem... de uma pessoa envelhecida... a superposição é muito difícil e nela você vê o espelho de você mesmo...". Espelho de si próprio, o momento do retorno significa também enfrentamentos de uma realidade objetivada num tempo que já passou e que deixou marcas inexoráveis, como também de confronto com seus sonhos e fantasmas... "Nós vivemos na inocência de acreditar no retorno..." (Vasquez \& Araújo, 1988, p. 208).

Outras dificuldades vivenciadas no retorno indicam que esta experiência, embora conduzida pelo mesmo eixo, é particular. Elisa, ao relatar seu retorno do exílio traz no semblante indagativo um olhar subversivo:

“A Anistia saiu em 20 de agosto de 1979... foi só o tempo de eu conseguir um passaporte pra mim e pro Matheus e eu voltei pro Brasil em 20 de setembro de 79. Saí com o Matheus... O Ciro não quis voltar.. ele estava começando a se reorganizar em Paris, a gente estava se instalando em Paris... ele quis ficar! Eu vim... Foi um período muito bravo porque eu não tinha dinheiro nenhum, tava morando na casa de uma amiga. O Matheus superdeprimido, porque ele era muito ligado ao Ciro... ficou dois anos deprimido... Tudo era muito difícil... a dependência dos amigos era muito grande, eu dependia dos amigos pra morar, pra conseguir trabalho... e meus pais estavam numa situação muito difícil naquela época, e meus pais estavam vivendo só com a aposentadoria dele... aposentadoria da Cosipa... os amigos é que seguraram...

[...] Aí eu comecei entender tudo o que tinha acontecido ao Matheus... como ele tinha sofrido... porque eu sempre achava que tinha tão poucas esse o sentimento de culpa que marca todo o exílio. O exilado se sente culpado de tudo e de nada... de tudo que tem dito mas sobretudo de tudo que não fez, no fundo dele mesmo, com uma linguagem sem palavras, cada um reconhece seu medo de morrer, em última instância, se o exilado se sente culpado de qualquer coisa é de ter escolhido a vida [...] o exilado se proíbe de viver no presente: o sofrimento de seus companheiros que estão distantes no Chile, no Brasil, está muito mais presente do que o presente na França. Porque não vive psicologicamente aqui e agora, ele concebe o tempo que deverá durar sua estadia fora de seu país como uma etapa, uma espécie de vida provisória, à espera de poder voltar a verdadeira vida, aquela que se registra no país" (Vasquez \& Brito, 1993, p. 54-55). 
pessoas conscientes no Brasil e que as crianças brasileiras sofriam tanto... que as pessoas conscientes tinham que fazer alguma coisa, que era muito cômodo cada um ficar na sua casa cuidando do seu filhinho, do seu maridinho... e que as pessoas conscientes tinham que fazer alguma coisa por milhares e milhares de crianças no Brasil. Eu achava que o Matheus estava tão superprotegido, que o Matheus não precisava tanto de mim... E depois eu vi que eu estava muito enganada... Se eu tivesse que repetir tudo eu não faria isso porque o Matheus realmente sofreu demais, e ainda hoje sofre as conseqüências disso... Foi uma coisa que eu vi... prejudicou tanto o Matheus ele sofreu tanto por causa disso... e eu acho que é pro resto da vida... Então eu tive que rever tanta coisa... se fosse possível conciliar uma luta assim... e os filhos...".

Mas Elisa não deixa, também, de acentuar as positividades da experiência para a vida de seu filho. Rememorando o passado, e no momento presente pensando no filho jovem e saudável, continua:

"[...] ele foi se adaptando... Aprendeu a falar inglês... Hoje em dia ele fala quatro línguas, é um professor de inglês! Então, tudo aquilo que a curto prazo exigia muito sacrifício, acabou sendo bom... eu acho que tudo foi muito sacrificado... exigiu muito dele, mas a longo prazo deu uma grande abertura... A cabeça dele é uma outra cabeça! Eu vejo os meninos da idade dele... Como o Matheus é diferente! Ele está aberto pra tudo... Como é um menino que aprendeu tanta coisa, que não tem preconceitos... ele vai em frente, tem força porque já lutou tanto... teve que transpor tanta dificuldade!"

A dor e a culpa são compensadas pelo aprendizado. O exílio de dez anos, buscando em diferentes países - como Cuba, Argélia, Inglaterra, Espanha e França - melhores possibilidades de trabalho para o companheiro e uma vida mais adequada para si e para a família, na condição de estrangeiros exilados, tornou-se a Anistia, para Elisa, o fato que dava um novo sentido à sua vida. Retornar era o sonho acalentado desde que saíra do Brasil. Em Cuba, onde fez treinamento de guerrilha, alimentava a ilusão de voltar ao Brasil para continuar a guerrilha. As notícias que iam chegando, no entanto, foram desestimulando o desejo. Trinta, dos trinta e cinco que com ela fizeram o treinamento, morreram nas garras da repressão. Acrescentavam-se, ainda, as notícias falsas de mortes de amigos e de companheiros que chegavam, confundindo a realidade, transformando as esperanças em devaneios! As 
GATI PIETROCOLLA, Luci. Anos 60/70: do sonho revolucionário ao amargo retorno. Tempo Social; Rev. Sociol. USP, S. Paulo, 8(2): 119-145, outubro de 1996.

passagens pelos diferentes países evidenciava cada vez mais a situação de "estrangeiros". Filha única que era, voltar livre para o Brasil significava acima de tudo retornar à presença e ao afeto dos pais já idosos e dos quais estava afastada há tanto tempo.

Retornar, no entanto, significava novos rompimentos afetivos. Elisa os esclarece: "saí com Matheus, o Ciro não quis voltar... A gente estava se instalando em Paris... ele quis ficar!” Mas significava também a possível reconstrução da vida e de reencontros! A tensão, no entanto, não obscureceu a esperança que mobilizou a ação. O retorno é a realidade do exilado!

No retorno ao Brasil, a precariedade e a provisoriedade próprias do viver entre parênteses continuaram a orientar a experiência "eu não tinha dinheiro nenhum... tudo era muito difícil... a dependência dos amigos era muito grande, eu dependia dos amigos para morar, pra conseguir trabalho... os amigos é que seguraram", conforme relatou Elisa. Soma-se a isto o empobrecimento dos pais que nos anos 60 possuíam uma residência grande no Jardim Europa, e agora estavam vivendo de aposentadoria no Rio de Janeiro. As viagens para a Europa tentando a proximidade com a filha e neto, consumiram suas economias. Mas a experiência vivida permitiu o afloramento de uma nova consciência como ela nos mostra: "Aí eu comecei entender tudo o que tinha acontecido ao Matheus... como ele tinha sofrido... Então eu tive que rever tanta coisa... se fosse possível conciliar uma luta assim... e os filhos...". Difícil a conciliação da vida afetiva voltada à família com aquela exigida pela opção revolucionária. A primeira suscita preocupações menores, corriqueiras às vezes, requer cuidados diários, atenção constante, afeto permanente, prazeres amenos, enquanto a segunda almeja a glória de mudar o perfil da sociedade ou do mundo e, neste sentido, é arrebatadora e subversora da ordem e dos códigos sociais estabelecidos. O banal e o heróico estão presentes na experiência. Esta situação característica do viver entre parênteses permite realizar uma aproximação com as noções de paixão revolucionária e paixão amorosa (cf. Ribeiro, 1988).

Renato Janine, ao escrever sobre a paixão revolucionária e a paixão amorosa em Stendhal, distingue o amor-paixão como sendo aquele sentimento que "de certa forma me prejudica, ou que prejudica, pelo menos, a minha integração na sociedade, a minha imagem pública externa”. Já o amor-gosto, continua ele, "obedece a um código preciso. É um jogo que torna agradável e amena a vida, que nela introduz uma certa porção de prazer, mas que por isso mesmo, jamais põe em cheque as posições ou valores sociais". Ele mostra a diferença entre ambos, afirmando que a paixão revolucionária, que tem como característica o arrebatamento, prevaleceu no Antigo Regime e entrou em crise com a Revolução Francesa. Janine remete-nos ao tom do amor, visível por excelência no trecho que segue: "Com a Revolução e o Império napoleônico houve um recuo do gosto ou, se quisermos, do bom gosto. Isso podemos notar já na busca de glória - que era, no Antigo Regime, a paixão por excelência, a que melhor mostrava o caráter ilusório de todas as paixões [...]. A glória 
dependia das convenções sociais, das quais também dependia o amor. Ora, o arrebatamento marca a Revolução: recordemos um quadro como o de David, O juramento do jogo da péla, no qual vemos os deputados que juram exaltados dar à França uma constituição, erguendo-se nas cadeiras, vivendo um momento que é glorioso, histórico, porque recusa o comedimento. A glória almejada, virá agora das batalhas revolucionárias, imperiais, que mudam o perfil do mundo, não mais da vida em sociedade; e mudará, também, a forma de travar batalhas" (Ribeiro, 1988, p. 418-420).

Janine, com seu relato, possibilita uma aproximação com a idealização do sonho revolucionário e do cotidiano nas suas tarefas menores e prosaicas. A grandiosidade da luta revolucionária, os ideais que subjazem às suas ações, os perigos e glórias aos quais ela remete o ator social entram em choque com a banalidade das tarefas habituais.

Retomemos as palavras de Ciro “... Nós éramos guerrilheiros... tinha uma aura de romantismo na figura do guerrilheiro..."; e depois disse: "Então eu ganho a vida fazendo coisas absolutamente desinteressantes". É na tensão entre a imagem do herói - também revelada pela imagem da mãe guerrilheira, como exprimiu Creonice - e as tarefas comuns, banais, como ser pai, mãe, trabalhar para sobreviver materialmente, que emergem as incertezas e os questionamentos em relação à própria identidade e aos princípios e códigos revolucionários.

Matheus, filho de Elisa, acrescenta outras dificuldades no seu relato sobre o próprio retorno ao Brasil:

"Quando cheguei eu não me sentia um brasileiro... Eu tava acostumado a ser estrangeiro... uma situação exótica, diferente... e aqui no Brasil quando eu cheguei eu tava perdido no espaço... eu não sabia o que eu queria... jornalista, administrador... depois... diretor de teatro. Ficava mudando, sem objetivo... mas hoje, não, estou me direcionando pra um objetivo na vida...

Eu tive experiência muito ruim em relação aos amigos porque quando a gente voltou pro Brasil, aqueles amigos adultos... dos meus pais... que eu via como meus amigos, as pessoas de esquerda... depois da separação [dos pais] eles se afastaram totalmente... a gente perdeu o contato com este pessoal. Então, tem algumas pessoas que só falam com a gente, agora, quando se trata de alguma campanha eleitoral... Eu passei a ver aquelas pessoas numa luz completamente diferente... aquelas pessoas boas, maravilhosas, que iam salvar o mundo... então não era nada disso... eu acabei sabendo de histórias... várias histórias de corrupção, pessoas que ganharam 
GATI PIETROCOLLA, Luci. Anos 60/70: do sonho revolucionário ao amargo retorno. Tempo Social; Rev. Sociol. USP, S. Paulo, 8(2): 119-145, outubro de 1996.

muito dinheiro, desviaram fundos... então a minha credibilidade nelas foi destruída. Muita gente se candidata a cargo eleitoral e fala: 'olha as minhas credenciais'. Eu fui exilado dez anos... preso ou torturado... Vejo muito oportunismo... mas muitas foram exiladas porque tinham mesmo um ideal... Eu acho que a gente tem que analisar pessoa por pessoa, independente do rótulo que ela tem na cabeça... o que vale é a pessoa, isso eu aprendi... porque me soa muito falso agora, que quando eu era criança... eram discursos maravilhosos... então eu me interesso por política... gosto de saber mas não acredito em partidos..."

Vivendo desde os cinco anos de idade em diversos países da Europa e da África, sendo obrigado a adaptar-se e a aprender o idioma de cada um deles, bem como a tentar entender os diferentes códigos culturais próprios de cada país desde muito cedo, Matheus perdera a identidade com seu país. Filho de exilados, habituara-se a ser estrangeiro. Mais ainda, gostara da experiência, porque esta situação tem um conteúdo de excepcionalidade a-paradigmática, como ele afirma: "ser estrangeiro... uma situação exótica, diferente..." O enfrentamento das dificuldades é amenizado pela aura de que é investido o exilado. Identidades esgarçadas. .. mas o respeito e a reconhecida admiração repõem o estatuto humano necessário à sobrevivência. Ilusão, elevação e transfiguração do eu mutilado enunciam o estado heróico.

Com o retorno ao país de origem, perde-se o estatuto de exilado. $\mathrm{O}$ reencontro com a antiga comunidade de destino não é mais o mesmo... Matheus cresceu entre adultos, teve poucos amigos, alguns colegas de escola, viveu e se desenvolveu entre os amigos dos pais. No retorno, veio a decepção em relação aos adultos, conforme expressou: "aquelas pessoas boas que iam salvar o mundo... a minha credibilidade nelas foi destruída". A visualização do oportunismo, utilizando a história vivida para conseguir cargos eleitorais, também é motivo de desapontamento para ele que critica a utilização do estatuto de exilado: "olha as minhas credenciais. Eu fui exilado dez anos, preso, torturado... vejo muito oportunismo...".

Matheus reconhece, no entanto, a existência de ideais humanitários orientadores da causa revolucionária: "mas muitas foram exiladas porque tinham mesmo um ideal...”. Outras decepções foram surgindo... O afastamento de Ciro, que preferiu ficar na Europa, legitimou a separação de seus pais. Este fato causou-lhe muita depressão, conforme relatou Elisa: "o Matheus superdeprimido porque ele era muito ligado ao Ciro... ficou dois anos deprimido...". Novas rupturas colocaram-se na rasteira das desilusões, restando o comportamento concreto de rejeição aos partidos políticos. A política, enquanto ação realizada através dos caminhos difíceis e tortuosos do cotidiano, é desprezada; como idealização, é bem-vinda. Se ela for arena de disputas 
GATI PIETROCOLLA, Luci. Anos 60/70: do sonho revolucionário ao amargo retorno. Tempo Social; Rev. Sociol. USP, S. Paulo, 8(2): 119-145, outubro de 1996.

Esta exposição foi inspirada no conceito de política de Chauí (1989). Para a autora, política não é a ruptura do direito civil e da lei ante o direito natural, mas expressão do fortalecimento do direito natural (potência de agir individual). Este dá origem ao direito civil e o exprime como seu efeito imanente. As declarações dos entrevistados sugerem que a ação política, na situação estudada, aparece muitas vezes como expressão e permanência de sentimentos passionais. A heroificação da ação revolucionária, da figura do revolucionário ou mesmo da experiência do viver entre parênteses responde, neste sentido, aos apelos invocados a partir desses sentimentos. Para os filhos dos revolucionários educados na Europa e lá ungidos pela aura de exilado, tornou-se difícil o enfrentamento do novo estatuto pósexílio. partidárias pela reconstrução democrática será repelida, à medida que aparece como catalizadora de dores e desencontros ocorridos num plano pessoal. Neste sentido, ela é tomada como algo autônomo, particular, imposto sobre as vidas das pessoas, orientando-as para o bem ou para o mal. Ela perde a força como agir individual e como expressão de afetos: é considerada paixão ${ }^{5}$.

A vida política do pai e da família foi, para muitos filhos, responsável pelo desencadeamento de dificuldades que só a heroificação do pai ou da experiência pôde compensar. Marilise, que viveu em Cuba, França e Chile, aponta os elementos para esta interpretação:

"Quando eu cheguei no Brasil eu tive uma dificuldade que era cultural... em relação ao jovem criado na Europa que não tem essa coisa de virgindade... Criança lá até doze, treze anos está brincando de boneca e bolinha de gude; com catorze namora com o primeiro namorado. No Brasil, não. A criança é hipersexualizada com sete. Aos seis já é paquita da Xuxa... em compensação tem mais problema com virgindade... é tabu! Então pode seduzir mas não pode dar... esse conflito é bem brasileiro... e nesse ponto eu dancei, eu cheguei com onze anos no Brasil... Eu fiquei super-chocada... era européia e me vi colocada numa crise de valores, não com a minha família mas com o meu meio que eram os meus colegas... também porque eu tava num colégio de caretas... um colégio grã-fino... onde as meninas tinham essa coisa de namorado rico..."

Mas tem um álibi que lhe parece grandioso, relatado com ênfase: "[...] A imagem do meu pai foi a imagem de herói... de um herói distante porque, primeiro, ele morreu quando eu era muito pequena, uma idade onde eu acho que as crianças são muito mais ligadas com a mãe do que com o pai; segundo, porque meu pai era um cara que trabalhava o dia inteiro e estudava à noite, então uma pessoa com quem eu tive não muito contato... Eu lembro de algumas cenas dele... eu tenho lembranças do meu pai... mas na verdade são lembranças afetivas... ... acho que lembranças de qualquer criança que tem um pai que morreu. Agora, é claro, óbvio que eu tenho orgulho... eu tenho uma arrogância que me faz... eu sou filha de um herói...e isso me faz ter uma altivez e eu acho que evidentemente que as circunstâncias da morte dele interferem muito nisso! Eu acho que se o meu pai fosse morto, sei lá, a tiros por um assaltante na rua eu 
GATI PIETROCOLLA, Luci. Anos 60/70: do sonho revolucionário ao amargo retorno. Tempo Social; Rev. Sociol. USP, S. Paulo, 8(2): 119-145, outubro de 1996.

acho que ia ser mais revoltada do que ele ter morrido na tortura... porque tinha um sentido pra isso... tinha um sentido... [...] Agora... que eu sempre me senti especial em relação a isto, é claro que eu me sentia! Eu era filha de um pai que morreu numa tortura, isso é uma coisa rara, eu sei que é raro, e eu me sinto rara... às vezes explico o meu jeito de ser em função disso... ... ... ... pô!! Eu sou assim porque meu pai morreu na tortura, e tem... não dá pra você ser inconseqüente quando teu pai morreu na tortura... não dá... tem coisas que me diferenciam hoje em relação às pessoas da minha geração”.

Choque de valores vividos por uma jovem educada na Europa. Lá, explica ela, "as crianças até doze e treze anos brincam de boneca e bolinha de gude". "Aqui”, continua, "a criança é hipersexualizada com sete. Aos seis já é paquita da Xuxa... em compensação tem problemas com virgindade... é tabu!". Assim, a adaptação é experiência complicada. Um meio social onde "as meninas tinham essa coisa de namorado rico" agride uma criança cujo pai morreu na tortura e "não dá para ser inconseqüente".

A mitificação da beleza, dinheiro e juventude é um fenômeno mais visível, por contraste, em sociedades mais pobres como a brasileira (cf. Gati Pietrocolla, 1988). As experiências de Marilise, as dores pelas perdas, o estranhamento no retorno são compensados pelo orgulho que tem do pai, dando sentido, desse modo, ao sacrifício e ao sofrimento. A política é vivida e interpretada pelos filhos dos revolucionários não como expressão de fortalecimento do direito individual, mas como expressão de um aprendizado fundado numa paixão. Sugere decorrência do estado heróico que a revolução, enquanto situação paradigmática, oferece às identidades enigmáticas chance de realização. Tendo a paixão como referência da política confirma-se a tese de Abensour de que o heroísmo é uma ilusão a um só tempo necessária (função de dissimulação) e eficaz (função de elevação e de transfiguração)" (cf. Abensour, 1992).

Mas o exílio possibilitou outras experiências e é na diversidade delas que podemos apreender melhor sua realidade. Para algumas crianças que nasceram no exílio e que foram socializadas na cultura e idioma da França, sem nada viverem da perseguição política junto aos pais, o Brasil constituía algo distante, feliz, paradisíaco. Era o espaço onde se encontravam os avós, tios, os primos, a mesa farta servida ao som da música alegre e festiva. Este país tão desejado pelos filhos porque avivado pela memória dos pais e experimentado através de curtas viagens de férias era desconhecido, na verdade. Foi dificilmente incorporado pelos filhos, no retorno. Estes, nascidos ou socializados na França, o foram, também, na cultura brasileira pela memória dos pais, dos amigos, dos companheiros de destino, pela música e reuniões plenas de nostalgia ou no "proche a proche" conforme mostram Igonet e 
Oriol (1984, p. 16). Esta socialização alimentava a imagem idílica do Brasil. Para estes, as dificuldades no retorno diziam respeito à contraposição sonho/ realidade - heróico/banal. As dificuldades de adaptação no retorno são relatadas por Guta:

"Para mim, o lado mais triste da ditadura eu não cheguei a conhecer.. para mim era uma festa... a minha casa [em Paris] era uma loucura... gente chegando... pessoas chegando... trazendo notícias... Eu conheci a ditadura através das músicas do Chico Buarque...

[...] Quando eu retornei ao Brasil, quando eu entrei no Equipe, eu comecei a conviver com os que hoje são meus amigos... Aí acabou tudo... eu era igual aos outros, caí no anonimato... Isso é difícil... [...] por um lado, isso foi bom porque eu precisava de gente parecida comigo... eu tava precisando muito disso, precisava chegar ao Brasil, conhecer gente como eu... Mas eu era perdida... um pé na França, outro no Brasil... Quando eu fui estudar no Equipe foi bom pelo fato de eu poder formar um grupo meu... mas ao mesmo tempo tem esse outro lado, que eu senti superpesado... todo mundo era igual a mim... como é até hoje... anonimato mesmo!"”

Sentimentos ambíguos permeiam a subjetividade e tornam-se mais intensos no momento com que se confronta a nova realidade: a Ítaca agora é desconhecida mas igualmente desejada como fôra para Ulysses. Muitas crianças cresceram ouvindo as histórias do Brasil, e muitas delas retornavam por breves períodos de férias escolares para conhecer e permanecer um pouco com os avós, tios e primos. A ditadura traveste-se em festa. A possibilidade da reunião de pessoas, notícias, música e o resgate, mesmo que momentâneo, da identidade nacional. Compartilha-se, também, nesses momentos, um espírito próprio da "comunidade de destino" da qual os exilados faziam parte. No retorno, o elã que a sustentava vai se diluindo. Os laços que asseguravam uma identidade do grupo no exterior vão se afrouxando, e sujeitos atomizados e anônimos lutando para se re-adaptar vão ocupando o lugar dos heróis. Sentimentos ambíguos de alegria e da carência de um referencial social transparecem na fala de Guta: "eu precisava de gente parecida comigo", contrapondo-se aos de tristeza "eu senti superpesado... [...] o anonimato", no difícil processo de reconstrução de identidade. Da despossessão do herói à ameaça da invisibilidade social repõem-se a dor e a angústia.

A desadaptação transparente nos discursos dos filhos de exilados brasileiros foi estudada por Vasquez (1983) com relação aos filhos de exilados na França. Tomou como exemplo, crianças brasileiras que cresceram e se formaram num duplo sistema de referências, que as faziam sentir-se mais 
GATI PIETROCOLLA, Luci. Anos 60/70: do sonho revolucionário ao amargo retorno. Tempo Social; Rev. Sociol. USP, S. Paulo, 8(2): 119-145, outubro de 1996.

ligadas à França do que ao seu país de origem. Segundo ela, muitas dessas crianças não tinham praticamente conhecido o Brasil, e sua língua de socialização era diferente da língua materna. Não conseguiam exprimir em português experiências vividas na França ${ }^{6}$.

Mas a tradução do cruzamento das duas culturas, o retornar ao Brasil torna os valores da cultura brasileira mais transparentes, evidenciados na rememoração da própria história pessoal: "sou filha de um herói... e isso me faz ter uma altivez... não dá pra você ser inconseqüente quando teu pai morreu na tortura... não dá... eu me sinto rara... tem coisas que me diferenciam hoje em relação às pessoas da minha geração". O sentir-se rara tem o mesmo significado que o exótico e diferente, já expresso por Matheus. Do herói político, o que prevalece, no entanto, é o herói construído no afetivo: “eu tenho lembranças do meu pai... mas na verdade são lembranças afetivas... eu tenho uma arrogância... eu sou filha de um herói!”. A lembrança pautada na emoção cruza-se na memória com a outra construída pela história vivida representada mais diretamente pelo grupo social imediato. É Júlio César, filho de um desaparecido quem diz: "todas as histórias que eu ouço de meu pai eu guardo, mas a que eu mais gosto mesmo... não é a parte militante... eu guardo ações cotidianas... escondida... a pessoa...". A figura pública do herói é obscurecida pela imagem afetiva, íntima e pessoal, mas é ao mesmo tempo a referência que legitima uma identidade construída na convergência da experiência individual e social.

Fundamentando-se em Platão, Pessanha afirma que a etimologia da palavra éros aproxima amor e herói. Após mostrar que todos os heróis são seres híbridos de "mortalidade/imortalidade, pois são nascidos do amor de um deus por um mortal ou de um mortal por uma deusa", acrescenta que "à luz da antiga língua ática, esse nome [herói] revela-se derivado de 'amor' (érôs) ao qual os heróis deveram seu nascimento!” (Pessanha, 1988, p. 8485). Assim a etimologia de éros legitima a existência subterrânea de relações afetivas concretas presente na construção da figura do herói. Ela é ratificada pela história contada destacando-se o sentido que teve a morte do pai para Marilise: "se o meu pai fosse morto, sei lá a tiros por um assaltante na rua, eu acho que eu ia ser mais revoltada do que ter morrido na tortura. .. porque tinha um sentido...". A admiração amorosa pelo sentido que teve a vida do pai faz dela uma pessoa especial "tem coisas que me diferenciam da minha geração".

Sem desconsiderar o social, a lembrança amorosa do pai-herói, nos casos de Marilise e de Julio César, o sentimento de perda e decepção "daquelas boas pessoas que iam salvar o mundo" informa sobre a experiência enquanto fenômeno particular.

No retorno, o Outro é a outra realidade e as relações "proche a proche" que garantiam a identidade do grupo são rompidas enquanto outras irão se construindo. É Paulo de Tarso quem reforça esta afirmação no seguinte depoimento:

\section{“[...] eu me sentia muito melhor vivendo toda aquela}

6 “eles não conseguem exprimir em português certas experiências vividas na França ou em francês, e quando estabelecem seus primeiros laços sociais na França, eles não podiam dividir com os adultos as lembranças idealizadas de antes do exílio ao mesmo tempo que têm poucos laços afetivos com o Brasil. São bilingües e biculturais" (Vasquez \& Apfelbaun, 1982, p. 91). 
fantasia dos anos 60 [...]. Aquele clima de dono da verdade, de que a revolução estava ali na esquina, só dependendo da gente, aquela utopia era muito viva. Se eu pudesse hoje voltar no tempo, provavelmente faria tudo de novo, talvez evitando as mortes dos companheiros queridos. Isso para mim foi duro: de repente fui o único sobrevivente do meu grupo. Isso às vezes me incomoda. Até brinco com meus amigos que estou fazendo hora extra. Equando você tem a sensação de fazer hora extra, a vida fica mais interessante" (Teoria e Debate, 15/08/1991, p. 35).

Um brilho no olhar... o passado emerge... a paixão se enuncia... o heróico se recoloca. Ficam a saudade e a nostalgia persistente!

\section{Os que não retornaram}

Se o sentido do exílio está no retorno, como interpretar a ação dos que permaneceram no país que os acolheu fazendo parte hoje dos milhares de imigrantes residentes na França, levando-se ainda em conta que, muitos deles, já adquiriram a nacionalidade francesa?

A declaração da anistia possibilitou aos exilados que retornaram ao Brasil a preservação da imagem de revolucionário reforçada durante o exílio. Para os que tentaram voltar mas não conseguiram, o circuito de construção desta imagem, a ser completado com o retorno ao país de origem, foi interceptado. A solução de permanência no país de acolhida sugere uma opção, na medida em que a anistia abriu as portas do país a todos os que desejassem entrar. Se podiam, por que não o fizeram?

Numa leitura apressada poder-se-ía afirmar que um lento e dolorido processo de apagamento da imagem de revolucionário foi ocorrendo, dando lugar a um outro, qual seja, o de imigrante inserido socialmente e integrado no mercado de trabalho. A opção pela permanência no país de acolhida descartaria possíveis desejos de retorno. A experiência da alteridade substituiria a nostalgia própria desta situação dramatizada através da Ítaca mítica de Ulysses.

A pesquisa realizada junto a ex-exilados radicados hoje em Paris trouxe outras revelações. Indicou que todos tentaram voltar ao Brasil mas alguns, por razões afetivas, não o conseguiram. A permanência no país de acolhida exigiu a realização de outros acordos afetivos construídos no decorrer do longo período de permanência no novo espaço.

Como no período do exílio, eles continuam sonhando com o retorno, sendo que para muitos o exílio continua : "um exilado é sempre um exilado", ouvimos mais de uma vez. No entanto, o ex-exilado político radicado no país de acolhida ou em outro país que escolheu, não é um imigrante comum, mas alguém que num certo momento da vida não pôde optar. $\mathrm{O}$ seu destino foi conduzido pela história política do país. A ausência do retorno à sua terra de 
GATI PIETROCOLLA, Luci. Anos 60/70: do sonho revolucionário ao amargo retorno. Tempo Social; Rev. Sociol. USP, S. Paulo, 8(2): 119-145, outubro de 1996.

origem no pós-anistia, impedindo a completude do circuito que constrói a imagem de revolucionário, transformou esse retorno num permanente objeto de desejo. Muitos entrevistados expressaram esse desejo e a frase de um deles: "gostaria de um dia voltar pra morrer lá" torna-o transparente. O interessante na experiência é que persiste a idéia da impossibilidade de escolha no passado. A idéia de exílio se traveste, sugerindo, num certo sentido, a preservação, mesmo opacizada, da imagem de revolucionário. Assim, a nostalgia apontada por Jankélévitch (1974) é vivida ainda hoje, o que indica que a questão nãoé espacial mas temporal. Confirmando Vasquez e Araújo (1988), o retorno diz respeito mais ao desejo inconsciente de reencontrar seu tempo, sua juventude do que um determinado lugar marcado pela geografia. De certo modo, a imagem sacrificada ao deixar o país, reconstruída e preservada durante o exílio, transfigurada pela situação de imigrante ou de naturalizado francês foi preservada. O contínuo desejo do retorno alimentado pelo impedimento, que não é mais o do Estado, mas outro, produzido ao longo dos anos, o evidencia. Razões subjetivas, mas também objetivas, explicam a permanência no país de acolhida. Marisa, vivendo hoje em Paris como funcionária pública do Estado francês, concedeu-nos uma entrevista, nessa cidade, na qual conta um pouco da sua história:

"Quando houve a Anistia eu voltei e foi superemocionante porque estava todo mundo me esperando no aeroporto, com faixas, foi muito interessante! Nesta fase eu estava no meio da minha tese, em Portugal, e era um compromisso com os trabalhadores da cooperativa e comigo mesmo. Voltei e foi um processo super-difícil porque você está vendo as pessoas sofrendo, um processo de destruição daquilo tudo, daquela esperança que eles construíram... Foi muito duro! Em 83 voltei para o Brasil, mas tinha que voltar aos poucos porque eu tinha uma integração muito grande aqui e em vinte anos construí minha vida, amigos... razões familiares... eu não podia voltar assim, quando todo mundo voltou... aí eu tive de me agüentar só com os franceses. Tive que colocar os pés no chão e dizer: "tenho que viver esta vida aqui, sem um pedaço que foi embora!"

Então, quer dizer, no fundo eu fiquei aqui por razões materiais e familiares mas a minha construção, a minha elaboração teórica, tudo aquilo que eu evoluo aqui, eu distribuo no Brasil... Foi a maneira que eu arranjei para não me desligar do Brasil... Desde 83 que eu vou regularmente ao Brasil... levo os melhores franceses que gostam de trabalhar os temas que no Brasil se precisa e organizei uma cooperação 
sobretudo com o Estado do Paraná que tinha uma grande receptividade, que era um Estado relativamente bem organizado, sobretudo com a Secretaria do Interior e Secretaria da Agricultura... Eram pessoas realmente progressistas, de esquerda, do meu tempo de faculdade... E conversei com eles e montei daqui, com um pouco de ajuda lá, este doutorado em Meio Ambiente e Desenvolvimento, que foi preciso para responder toda esta temática da Amazônia, os grandes problemas brasileiros, as grandes barragens, as grandes obras com todos os impactos que a gente conhece... sociais e catastróficos... Eu achava que isto não é um problema de meio ambiente, isso é um problema do desenvolvimento... e que tinha que construir uma escola, um pólo que aglutinasse e começasse a produzir saber. Eu já comecei e terminei três grandes projetos de pesquisa. Este agora é o quarto projeto com doutorado onde tem quatro universidades francesas implicadas. Foi a minha maneira de tentar colaborar, sem me desligar!

Bem, eu dei minha contribuição, vou continuar indo lá de vez em quando... agora tenho vontade de escrever um livro... fazer outra coisa... de repente... Mas ao mesmo tempo não me vejo integrada aqui com uma problemática completamente européia, francesa... O fato de que eu não me liguei com nenhum país da Europa... em Portugal me desliguei com tudo que tinha lá... eu conhecia Deus e o mundo, circulava em tudo que era meio de trabalho... não mantive! Tinha possibilidade na Itália, na Inglaterra e nunca liguei porque eu não sou uma internacional sozinha. Eu não posso me ligar com todo esse povo e estar ligada ao Brasil, a ponto de ir três, quatro vezes por ano para ajudar montar as coisas lá...

Eu tentei conciliar a minha militância com uma atividade de pesquisa... tudo que eu aproveitava das minhas aulas eu organizava em termos teóricos e fazia os meus cursos... a minha problemática era a problemática do desenvolvimento... no fundo tem suas implicações políticas muito crescidas! E trabalhei aqui com vários aspectos dos movimentos alternativos franceses, os movimentos rurais, a volta ao campo, toda a construção de um projeto alternativo 
GATI PIETROCOLLA, Luci. Anos 60/70: do sonho revolucionário ao amargo retorno. Tempo Social; Rev. Sociol. USP, S. Paulo, 8(2): 119-145, outubro de 1996.

com os meus alunos... O interessante é que eu me integrei no Chile, me integrei em Portugal, me integrei aqui... e eu tinha o Brasil como o meu pano de esperança... mas estas coisas estão acontecendo em outros lugares, a revolução não terminou... mas eu sempre tive uma esperança... um dia a gente vai voltar!".

A ambiguiidade é experimentada através do desejo de permanecer no país de acolhimento e de retornar ao país de origem, conforme afirma a entrevistada: "eu não posso me ligar com todo este povo e estar ligada ao Brasil [...] mas eu sempre tive uma esperança... um dia eu vou voltar!" É no movimento marcado por sentimentos contraditórios, próprios do esforço despendido para garantir a sobrevivência no novo espaço, que os afetos foram se situando e seu destino foi se construindo. Retomemos as suas palavras: "em 83 voltei para o Brasil, mas tinha que voltar aos poucos porque eu tinha uma integração muito grande aqui e em vinte anos construí minha vida, amigos... razões familiares eu não podia voltar assim, quando todo mundo voltou... aí tive que me agüentar só com os franceses". Se a racionalidade substitui o sonho - "tive que por os pés no chão"-, o cotidiano prosaico substitui as grandes emoções da luta revolucionária - "tenho que viver esta vida aqui". Suportar e elaborar a dor da perda do "pedaço que foi embora" constitui a nova tarefa. Vasquez (1983), ao tratar a crise de identidade do exilado em face da sua permanência no país de acolhida, quando se inicia um certo apagamento da esperança de retorno, mostra a ambigüidade em que vive o exilado ao ir assumindo a nova identidade ${ }^{7}$.

Parte-se do pressuposto de que uma certa melancolia se esconde por detrás da racionalidade e transfigura o exílio, não apenas numa entidade, como aponta a autora, mas num valor (cf. Jankélévitch, 1974) cuja manutenção subjetiva vai ocorrendo lentamente através dos anos, misturada com o processo de incorporação da cultura do país de acolhida. Poderíamos mesmo afirmar que a defesa do exilado contra o anonimato e a invisibilidade, tal como ocorre com os imigrantes comuns, principalmente aqueles considerados como de uma "cultura inferior" pela cultura do país que escolheram para viver, leva o exilado a preservar esta condição. Para alguns, como Marisa, um comportamento expresso por uma "revolução possível" garante a identidade de ex-exilada e traduz também a impossível perda da identidade nacional: "a minha elaboração teórica, tudo aquilo que eu evoluo aqui, eu distribuo no Brasil... foi a maneira que eu arranjei para não me desligar do Brasil... [...]. Foi a minha maneira de colaborar sem me desligar!". Amores em diferentes continentes requerem dedicação, mesmo que projetada à distância. Lá e aqui constituem o espaço temporal e geográfico no qual as experiências vão sendo vividas e as identidades reconstruídas.

Dos exilados brasileiros que lá permaneceram, embora engajados profissionalmente em boas condições no mercado de trabalho, a maioria idealiza
7 "Em parte pelo esquecimento, em parte pela imposição da realidade, a identidade anterior começa a se extinguir. É quando as representações mudam e o 'aqui' (a vida na França) vai sendo progressivamente percebida como uma realidade aceitável; cada um é obrigado a reconduzir o seu tempo histórico do exílio à dimensão de sua própria vida e, assim, os problemas colocados pela situação de exílio são explicitamente vividos como problemas individuais. Definir-se em relação ao futuro e avaliar a duração de seu prórprio exílio (e não mais daquela entidade 'exílio'), ser capaz de recomeçar estabelecer projetos mais modestos, mais realistas, é assumir sua vida aqui e reencontrar o seu próprio lugar. É o momento no qual os exilados se perguntam se eles estão perdendo sua identidade nacional" (Vasquez, 1983, p. 9091). 
um retorno futuro. Muitos são hoje mediadores entre as duas culturas, como Marisa por exemplo. Permanecem entre as duas. Relações familiares e amigos ligam-nos ao país de origem; novos amigos, amores e formação profissional os retêm no país de acolhida. As situações são diversas e particulares. Mesmo havendo um certo apagamento das relações com o Brasil, ele está sempre presente em suas vidas. As ligações são visíveis tanto numa feijoada degustada em reuniões com brasileiros e franceses, no acompanhamento da política brasileira, na participação de alguns em partidos políticos brasileiros - cuja existência é notada na França - ou na presença nos eventos políticos e sociais brasileiros na França. São modos expressivos de manutenção de laços afetivos. Uma formação profissional voltada para o mercado francês constituiu para alguns, também, uma dificuldade real para enfrentarem o retorno. Os que estão envolvidos com pesquisa científica - como a maioria dos que foram entrevistados - insistem em afirmar a extrema dificuldade de retornar ao Brasil, em virtude do trabalho que desempenham no país de acolhida. Condições objetivas de existência asseguradas como melhores no primeiro mundo, dentre elas a assistência social, o profissionalismo nas relações de trabalho, o acesso a bens sociais e de consumo em geral, justificam a insegurança ou mesmo a impossibilidade de recomeçar no Brasil. Conforme palavras de Marta, exexilada, médica de formação, hoje trabalhando no Museu do Homem em Paris, especializada em Antropologia, "num determinado tempo não é você que escolhe mas a vida que determina". Após muitos anos se especializando em Antropologia a partir da medicina, ela não vê como poderia exercitar tal aprendizado no Brasil. Retornar ou permanecer fogem às outras determinações de ordem pessoal e se circunscrevem às contingências de ordem afetiva existentes na vida profissional e familiar. A interdição do retorno não é mais determinada pelo Estado, mas sim pelos novos afetos construídos ao longo da vida, nestes quase trinta anos.

Entende-se que, no encadeamento confuso dos sentimentos, uma certa nostalgia, contrapõe-se à alegria. É lenta e difícil a transformação do estranho em familiar. Mas as dores pelas perdas sofridas no processo de incorporação dos elementos fundamentais da nova cultura são compensadas pelo efetivo sucesso dessa mesma incorporação.

Uma disponibilidade para ser feliz está por trás da frase de Tadeu, ex-exilado político que vive há mais de vinte e cinco anos em Paris: "si je n'ai pas de chez moi, chez moi c'est partout'. Geografia errante sugere desapego, desenraizamento, mas insinua também uma dimensão da experiência humana que só pode ser explicada por sua origem em mecanismos afetivos, responsáveis pela eterna recriação de experiências e busca humana da felicidade. Bruhl, estudado por Roberto Cardoso de Oliveira (1991), mostra a existência de uma lógica dos sentimentos constituindo o eixo da natureza afetiva do homem. É ela que o compatibiliza com seu ambiente natural e humano na busca da própria sobrevivência. Sendo então movida por sentimentos, esta busca não é apenas instrumental, mas é também emocional. O afetivo, para Bruhl, é o principal 
GATI PIETROCOLLA, Luci. Anos 60/70: do sonho revolucionário ao amargo retorno. Tempo Social; Rev. Sociol. USP, S. Paulo, 8(2): 119-145, outubro de 1996.

componente do pensamento místico que constitui o eixo da mentalidade primitiva tendo, por isto, um sentido de totalidade. Recuperando o elemento místico-afetivo na mentalidade primitiva afirma que é ele que possibilita a ordenação de um mundo mais sentido, portanto vivido, do que conhecido. Parte do primitivo para mostrar que a razão e afetividade são universais no pensamento e no espírito do homem. "Sem dúvida - diz L-B - esta [experiência afetiva] tem também por função instruí-los [os povos primitivos] sobre o meio no qual devem a cada instante se adaptar, sob pena de desaparecer [...]. Mostra que a necessidade de adaptação se constitui na 'primeira das condições de existência' para qualquer ser vivo, inclusive o ser humano" (Oliveira, 1991, p. 129). É Espinosa quem, ao estudar a natureza humana fundamentada no sentimento, afirma: “[...] ninguém, na esperança de recuperar o dano a si causado, desejará causar dano a si mesmo, nem quererá estar doente na esperança da convalescença. Na verdade, cada um se esforçará sempre por conservar o seu ser e, tanto quanto está em seu poder, por repelir a tristeza" (Espinosa, 1973, p. XLIV:20).

Embora sejam muitas e diversas as experiências vividas por exexilados que permaneceram no país de acolhida, pode-se afirmar que a lenta transfiguração subjetiva do exílio num valor atribui a este elemento o caráter diferenciador quando se comparam ex-exilados com os imigrantes comuns. Tomando-se a imagem que o indivíduo tem de si como elemento construtor de sua identidade pessoal, é visível a diferença entre ambos porque é o exílio, enquanto valor, que garante a manutenção da percepção positiva que o exexilado tem a seu respeito. Ele não é um imigrante comum que partiu em busca de melhores condições de vida ou por fuga da pobreza no país de origem, mas alguém que num determinado momento da vida não pôde optar e teve seu destino determinado pela repressão instaurada em seu país. A consciência de que faz parte de um processo que o ultrapassa, mas ao qual está vinculado em virtude de seu projeto individual e ideológico, confere um caráter de historicidade ao seu destino. Mesmo desaparecendo ao longo dos anos, a imagem de "militante heróico em exílio" - transformada num valor - favorece ainda hoje, segundo esta investigação, a reestruturação da sua identidade e da referência a novos grupos. Uma questão curiosa é levantada por Cardoso ao se referir aos diferentes sentidos do esquecimento como cicatrização. Reportando a um deles, mostra que a atitude de exorcização do passado "ao torná-lo outro, produz as condições de sua completa inteligibilidade e de recuperação de uma plenitude anterior, marcada pelo completo distanciamento e pela lucidez. Este sentido encontra eco ainda na perspectiva do militantismo, que procura recuperar uma plenitude anterior do passado a partir da construção de uma inteligibilidade do erro e da verdade (do acerto) a que são submetidas retrospectivamente as ações políticas, no acontecimento. Nessa visão, o que houve foi uma inadequação da estratégia à conjuntura: percepção recorrente numa certa linha interpretativa da história daqueles acontecimentos. A revolução faltou ao encontro por um erro basicamente de estratégia política" 
(Cardoso, 1993, p. 64). Este texto ratifica a afirmação que vem sendo feita sobre a identidade do herói revolucionário: ela contínua viva, mesmo que esmaecida, em muitos casos.

Vasquez e Apfelbaum (1983), num artigo sobre a questão da identidade proveniente de um duplo sistema de normas e referências, analisam a diferença entre identidade de exilados e imigrantes espanhóis e portugueses na França. As autoras têm uma perspectiva diferente: afirmam que a vida no exílio, a incorporação da nova cultura, o crescimento dos filhos socializados na cultura francesa, a discussão do status quo frente a outros modos de vida, a revisão do discurso libertário, a crise ideológica das esquerdas e dos partidos do exílio em particular, favorecem o desaparecimento da imagem do militante "heróico em exílio", provocando a abertura de brechas na identidade do exilado. Tal situação favorece a reestruturação da identidade a partir de outras dimensões e referências a novos grupos. O ex-exilado vai incorporando ao longo do tempo o estatuto de imigrante

A investigação junto a ex-exilados brasileiros radicados hoje em Paris, apontou, no entanto, para uma análise diferente da realizada por Vasquez e Apfelbaum. Ocorre, para estes, a transfiguração do exílio num valor mantendo, mesmo que recôndita, a permanência do exílio na configuração de sua identidade. É verdade que outros elementos foram acrescentados, alterando a percepção que tinham de si mesmos, como apontam as autoras. A questão profissional, por exemplo, para aqueles que já possuíam uma profissão no Brasil, vai exigir um investimento pessoal marcado por sérios conflitos de identidade e estabelecimento no país de acolhida. Por detrás da frase "um exilado é sempre um exilado" encontrada na fala da maioria dos que foram entrevistados, apreende-se a consciência que têm da existência de um processo histórico que os ultrapassa, traça os seus destinos mas particulariza a experiência. Essa particularidade lhes assegura uma identidade distinta da do imigrante comum. O valor embutido na construção da identidade se refere ao corte brutal que o revolucionário foi obrigado a fazer com o aquilo que dava sentido às suas ações: a transformação da sociedade em que vivia. Sonhos desfeitos, desejos frustados, desesperança e raiva não constituem ingredientes positivos na mobilização de sentimentos necessários ao enfrentamento do novo.

Tomando ainda Vasquez e Apfelbaum, o imigrante (português ou espanhol), além do partir fundado numa escolha pessoal, não passa por fortes rupturas físicas e emocionais relacionadas com os lugares de origem. Ao contrário, as ligações se mantêm diante da proximidade geográfica. O mais significativo para elas, acentuando o sentimento de estrangeiro, é a mudança radical no modo de vida, qual seja, de rurais para citadinos. Acrescentam-se ainda as dificuldades que a política francesa vem impondo à imigração, reafirmando a discriminação em relação a alguns grupos estrangeiros, identificados como "estrangeiros pobres". Isto impede que o estatuto de imigrado abra perspectivas nos grupos nacionais. A possibilidade de opção do imigrante, permanecer ou partir da terra natal, já o coloca, por princípio, 
GATI PIETROCOLLA, Luci. Anos 60/70: do sonho revolucionário ao amargo retorno. Tempo Social; Rev. Sociol. USP, S. Paulo, 8(2): 119-145, outubro de 1996.

em posição oposta ao do revolucionário: é ele que deseja romper os vínculos, deixar o país e o investimento na busca e estabelecimento em outro país o faz sujeito que age e não o que reage como o exilado. Ele agiu na mudança do seu destino e a sua perspectiva é individual ou familiar. Nenhum compromisso político o vincula ao país de origem e nem ao de chegada. Vencer é a sua meta. Vencer no estrangeiro exige a mobilização de sentimentos e de uma energia diferentes daqueles vivenciados pelos revolucionários. Arrojo, tenacidade e muita positividade são sentimentos que devem nortear a opção e o enfrentamento da aventura. $\mathrm{O}$ fortalecimento do ego a disposição para vencer são os suportes para os novos enfrentamentos. O imigrante, diferentemente do exilado, tem uma concepção instrumentalista da cultura do país de acolhida, tentando adotar certas normas e modos de vida que consideram instrumentos de sucesso. Permanecer na França para estes mantém a esperança do sucesso desejado e contribui para alimentar a sua boa imagem no país de origem. Permanecer no outro país, transitar de um para o outro constitue, para o imigrante, mostra de sucesso pessoal, favorecendo o enfrentamento das dificuldades no "estrangeiro". Na verdade, é a idéia de promoção e sucesso social - mito decorrente das primeiras levas de imigrantes - que sustenta este comportamento.

Embora os ex-exilados que permaneceram no país de acolhida o tenham feito em virtude do sucesso afetivo e profissional que lá acabaram por encontrar, o sentido de sua ação, ou seja, o permanecer no país, é diferente. Estes o fizeram em virtude não mais de uma opção anunciada e realizada, mas do próprio movimento da vida, aleatório à sua escolha, como afirmou Marta : "num determinado momento nãoé você que escolhe, mas a vida que determina".

Recebido para publicação em maio/1996 


\section{UNITERMS:}

revolutionary hero,

identity,

exile,

furtiveness,

return.
GATI PIETROCOLLA, Luci. The 60s and the 70s: from the revolutionary dream to the bitter return. Tempo Social; Rev. Sociol. USP, S. Paulo, 8(2): 119-145, october 1996.

\section{REFERÊNCIASBIBLIOGRÁFICAS}

BosI, Ecléa (1987) Memória e sociedade. Lembranças de velhos. São Paulo, T.A Queiróz Editores/Edusp.

Abensour, Miguel. (1992) O Heroísmo e o enigma do revolucionário. In: Novaes, Adauto (org.). Tempo e história. São Paulo, Secretaria Municipal da Cultura/Companhia das Letras. p. 205-37.

CARdoso, Irene de Arruda Ribeiro. (1993) A dimensão trágica de 68. Teoria \& Debate, São Paulo, Revista Trimestral do Partido dos Trabalhadores, (22): 59-64, set/out/nov.

Chauí, Marilena. (1988) Sobre o medo. In: Cardoso, Sergio \& Novaes, Adauto (coord.). Os sentidos da paixão. São Paulo, Companhia das Letras. p. 36-75.

(1989) Direitos humanos e medo In: Direitos humanos e... São Paulo, Comissão de Justiça e Paz/Brasiliense.

EsPinosA, Baruch. (1973) A ética III. In: Espinosa. Coleção Os Pensadores. São Paulo, Abril Cultural.

Gati Pietrocolla, Luci. (1993) Anos 60/70: A cultura do medo orientando vidas e trajetórias no Brasil. Cadernos CERU, São Paulo, série 2, (4): 92-111.

(1995) Anos 60/70: O viver entre parênteses. A perseguição política aos revolucionários e suas famílias. São Paulo, Tese (Doutorado). Faculdade de Filosofia Letras e Ciências Humanas da Universidade de São Paulo.

IGONET, Fastinger \& ORIOL, Michel. (1984) Recherches sur l'identité: le return paradoxal du sujet dans les sciences sociales. Revue de Recherches Sociologiques, Paris, XV (2-3): 155-166.

JANKÉLÉVITCH, Vladimir. (1974) L’irréversible et la nostalgie. Paris, Flamarion.

KASTERSZTEIN, Joseph. (1990) Les stratégies identitaires des acteurs sociaux: approche dynamique des finalités. In: Stratégies 
identitaires. Paris, PUF. p. 27-41.

Matos, Olgária. (1988) A melancolia de Ulisses. In: CARdoso, Sergio \& NovaEs, Adauto (coord.). Os sentidos da paixão. São Paulo, Companhia das Letras. p. 141-57.

Oriol, Michel. (1979) Identité produite, identité instituée, identitée exprimée. Cahiers Internacionaux de Sociologie. Vol. LXVI. Paris.

Oliveira, Roberto Cardoso. (1991) Razão e afetividade. O Pensamento de Lucien Lévy-Bruhl. Campinas, Ed. Unicamp.

Pessanha, Jose Américo Motta. (1988) As várias faces do amor. In: CARDoso, Sergio \& NovaEs, Adauto (coord.). Os sentidos da paixão. São Paulo, Companhia das Letras. p. 77-103.

RIBEIRO, Renato Janine. (1988) A paixão revolucionária e a paixão amorosa em Stendhal. In: CARdoso, Sergio \& Novaes, Adauto (coord.). Os sentidos da paixão. São Paulo, Companhia. das Letras. p. 417-34.

SchILling, Flavia. (1991) Estudos sobre resistência. Campinas. Dissertação (mestrado). Departamento de Educação, UNICAMP.

Vasquez, Ana \& Apfelbaum, Erika (1983) Les réalités changeantes de l'identité. Peuples Mediterraneens/ Mediterranean Peoples. L'Identité Déchirée, Paris, (24): 83-102, juil-sept.

\& Araúso, Ana Maria. (1988) Éxile latino-americaine. La malédiction d'Ulysses. Paris, Ciemi-L'Harmattan.

. \& XAVIER Brito, Angela. (1993) La situation d'éxile: essai de genéralisation fonde sur l'exemple de refugiés latino americains. Intercultures, Paris, (21): 51-66, avril.

. (1982a) Des troubles d' ídentité chez les exilés. Amerique Latine, Paris, $\mathrm{n}^{\circ} 12$, oct-déc.

. (1982b) Mujeres en el exilio. La perception del exilio de las mujeres exiladas en Francia. Mensaje, Paris, no 314, nov.

. (1982c) Temps social, temps culturel. Enfance. Paris, CNRS(5): 335-350, nov-déc.

(1983) L'éxil, une analyse psycho-sociologique. L' Information Psychiatrique, Paris, 59 (1): 43-58, jan. 
GATI PIETROCOLLA, Luci. Anos 60/70: do sonho revolucionário ao amargo retorno. Tempo Social; Rev. Sociol. USP, S. Paulo, 8(2): 119-145, outubro de 1996. 